\title{
PRIVATE INTERNATIONAL LAW / CONFLICT OF LAWS AND DIAMOND TRADE
}

\author{
Fikile Portia Ndlovu
}

LLB LLM PhD

Senior Lecturer, Faculty of Law

University of KwaZulu-Natal, Durban

\section{SUMMARY}

Any researcher of South African diamond laws would find it inevitable that such research discusses the relationship between international diamond transactions and conflict of laws. This is particularly evident in cases where legal disputes have arisen pertaining to such transactions. This article will make reference to the terms "private international law" and "conflict of laws" interchangeably, although "conflict of laws" will be preferred for reasons of taste rather than logic. The aim of this paper is to illustrate the concept of conflict of laws in general and how it significantly impacts the manner in which courts will ultimately decide on the law to be applied in a matter possibly involving inter alia international diamond transactions. This demonstrates the consistent relevance of conflict of laws particularly in light of the global economy. The correct identification and understanding of conflict of laws' principles can be stretched to accommodate all other areas of international trade. However, for the purposes of understanding how diamond trade is impacted by conflict of laws in South Africa, this paper will be limited to the legal context of diamond-relevant trade and the latest guidelines provided by our courts in relation to the choice of law in matters where conflict of laws has arisen.

\section{INTRODUCTION}

Modern diamond trade transactions have increasingly become international. This observation supports the fact that naturally diamond trade has always been intercontinental in nature. It is also important here to note that states, through state custodianship over its individual countries' natural resources and through the establishment of bodies such as in the case of South Africa, the State Diamond Trader (SDT) states are able to engage effectively in the buying and selling of diamonds. ${ }^{1}$ On the other hand there are also private diamond dealers who represent their own private economic interests such as private individuals and private companies. These diamond dealers, whether as state or private entities, all represent participants in the diamond industry who make a contribution to national economic activity and the increment of national revenue.

See the Diamonds Act 56 of 1986 . 
Fewer states in the Third World club, however, produce and export their diamonds among themselves and/or between each other although in keeping with neighbourly trade agreements such as those overseen by the Southern African Customs Union (SACU), for example. Trading in natural resources among such states is encouraged at more trade-friendly export and import tariff agreements. Further, to continue trade in diamonds for the benefit of national revenues generally private individuals or companies within these states are able to purchase diamonds freely within the acceptable legal regulations observed by such states. Having considered the participants in diamond trade transactions it is important also to consider some of the patterns of diamond trade demonstrated historically and practically by these bodies as they will illustrate why conflict of laws often becomes applicable in such trade.

While the above paragraphs have broadly discussed diamond trade trends in Third World states, it is also historically common for these states and some of the private buyers therefrom to have increasingly looked to markets in First-World states as a result of high prices which buyers in the First-World markets are willing to pay for diamonds. The other reason is that most diamond-mining companies in developing states are owned and operated by multinational companies incorporated in the First-World states. This means that it is in the best interest of such large multi-nationals to attract the economically viable markets of the First-World states. Most of the mining companies in developing states are therefore subsidiary to the parent or group holding company that controls various other subsidiaries in various countries. $^{2}$

These trading routes and relationships resemble a colonial hang-over since most former colonies export to former colonizers. Diamond-producing entities have also sought to benefit from advanced financial, transport and communication systems servicing first-world trading routes and markets. It would for instance be cheaper and more convenient for Cote D'lvoire to export diamonds to France, its former colonial master, than for the same country to export to Armenia. ${ }^{3}$ Be that as it may, diamond trade transactions may involve more than one state entity. This means diamond trade transactions may involve more than one legal regulatory framework particularly when considering that various states may be involved. These states may be involved in providing transport systems, banking and financial services, insurance, airports, personnel, markets and storage facilities. The involvement of various legal systems brings into the picture the aspect of conflict of laws in diamond trade transactions. ${ }^{4}$

2 See generally World Bank World Development Indicators 2001 (2001) 396. An example of such a diamond trading multi-national is Anglo-American.

3 The one reason, among others, is because there are already pre-existing trade, routes, usages and trends that make it almost natural for such a state to continue to export according to this trend.

4 As highlighted, this discourse will prefer "conflict of laws" more than the other term "private international law". 
Conflict of laws essentially refers to the body of rules within a national legal system that local courts would select as appropriate to govern disputes with a foreign element. ${ }^{5}$ Conflict of laws is therefore not supranational and therefore not similar to public international law; it is not a legal system regulating the relations between states but implies the assessment of a body of rules in a national legal framework in order that the most appropriate rules can be selected to govern and resolve a dispute. Conflict of laws is part of the private law of each country that deals with cases with a foreign element. Unlike public international law, private individuals are involved and not state entities. Three main issues involved in conflict of laws are:

(i) which court has jurisdiction to resolve the dispute;

(ii) which law that court will apply to the dispute; (this means that a court has a set of conflict of laws rules that it must apply to find the law which will apply to the dispute. These conflict of law rules are also referred to as choice of law rules); and

(iii) recognition and enforcement of the judgment. ${ }^{6}$

\section{THE NATURE OF DIAMOND TRADE TRANSACTIONS}

Diamond trade transactions are not difficult to regulate when they involve for instance South African citizens resident in South Africa and where the cause of action arose in South Africa, and the country is also the place of business for these parties. The South African courts would ordinarily have jurisdiction and South African law such as the Diamonds Act 56 of 1986 would be applicable. The judgments would also be enforceable in South Africa. Complications arise where the dispute involves one or both parties who are neither citizens nor permanently resident in South Africa. Further, some difficulties would arise where it is not clear where the cause of action arose and there is no specific legal system selected as the proper law of the contractual agreement.

Since diamond transactions are by nature marked by contractual agreements of commercial nature this part of this paper will be limited to giving a general overview of conflict of laws in such relevant contractual scenarios where conflict of laws would arise. This means that this paper will be branded by commercial considerations and scenarios that may commonly characterize diamond trade transactions. It is submitted that this understanding of conflict of laws as related to the diamond industry can be useful for application in other areas of commerce as well as making an essential academic contribution to other areas of international trade.

Forsyth Private International Law 4ed (2003) 3-5.

O'Brien Smith's Conflict of Laws 2ed (1988) 315-324. 


\section{International contractual relationships}

There exist certain common-law rules that govern international contractual agreements. Some of these rules have found their way into international conventions that seek to codify common rules to apply when a court is determining choice of law to apply to cases with a foreign element. Important rules that courts refer to when a contractual case with a foreign element has come before them include lex loci contractus (law of the place of contracting), lex loci solutionis (law of place of performance) lex monetae (law in whose currency the debt is expressed). ${ }^{7}$

In the context of diamond trade contracts, this would imply the law of the country where the contract was made, or law of the place where the contract was performed. Usually diamond contracts express monetary obligations in the United States dollar albeit without necessarily intending that the contract be governed by United States law. It is important to note that most of these rules apply where the contract does not specify the proper law to govern it.

Some local South African statutes make specific provision for choice of law in particular contractual contexts. These include the Bills of Exchange Act 34 of $1964,{ }^{8}$ the Insurance Act, ${ }^{9}$ the Carriage of Goods by Sea Act 1 of $1986^{10}$ and the Admiralty Jurisdiction Regulation Act 105 of 1983. However, most of these statutory provisions codify Roman-Dutch law and are thus not fundamental departures from the common-law position.

Notwithstanding these positions, it is submitted that the proper law of the contract is one chosen by the parties or, if this is not chosen, the law with which the contract is most closely connected. ${ }^{11}$ Only where the choice of both parties to the contract does not provide any useful guidance as to the proper law to govern the contract will the courts seek to assign to the contract a chosen law in accordance with the above stated maxims and others. ${ }^{12}$ The maxims relate to the notion that the law which is most closely connected to the dispute is the applicable law. This notion also suggests that the courts would in the main weigh the factual links between the contractual agreement and the various relevant legal systems. The one ordinarily

\footnotetext{
7 Forsyth 5-11; and Standard Bank of South Africa Ltd v Efroiken \& Newman 1924 AD 171 is an example of a decision where the appeal court investigated various legal systems as expressed in the forms above. This case illustrates that the choice of law as applied by the forum court is capable of bringing about an outcome that may effectively nullify a contract as a result of a technicality that may be present in one system of law and absent in another system of law. The courts have had to re-consider the approach to choice of law and the latest guidelines reveal that the choice of law must take into account good relations with other states involved in the matter.

S 70

S 63(1).

S 1.

Forsyth 294-295.

Ibid.
} 
applicable as the proper law would be the legal system with which the contract has the closest and most real connection. ${ }^{13}$

An example of this notion as discussed by the courts from an international perspective can simply be understood as follows: If a contract with a foreign element was for the most part formulated and performed in China and written in the Chinese language and signed by Chinese nationals who have also agreed to use Chinese currency, in such a case it would appear that this particular contract would be factually linked to Chinese law, having used all these connecting factors to determine the applicable law.

English authors in the area of conflict of laws, Cheshire, North and Fawcett, submit that there are tests that can be used to determine the law that is mostly connected with a contract. They submit that an objective test can be used which is determined by looking objectively at all the connections, unlimited by any categorization of the relevant factors and thereby linking the contract to a particular country. They also submit that a severing of the contract test can be used by the courts in their power to determine the applicable law in a case of conflict. This test works when one part of the contract has its closest connection with one country in part and has another part to it which is closely connected with another country. The authors submit, however, that this test may only work if there is indeed a severable part of the contract such that part of the contract is independent from the rest and can be severed from it, for example joint ventures and complex contracts. ${ }^{14}$ While this method is complex as it requires a contract which is a single transaction to suddenly take a complex disjointed form, this test shows that at all times the courts, when looking at the law which is mostly connected with the dispute, objective factors linking such a contract to a particular country will serve as an important guideline for the court when faced with a conflict of laws situation.

\section{Passing of ownership: movable property and the lex situs principle}

As in any ordinary contract of sale, passing of ownership and risk in the commodity subject to the sale contract also arises in international diamond sale agreements. Diamonds are movable property and any case dealing with passing of ownership and risk in South African law of sale is a useful guide as to how local courts are likely to consider disputes in this area.

Conflict of laws regarding ownership of movable property was considered by the court in the case of Marcard Stein \& Co $v$ Port Marine Contractors

\footnotetext{
13 Morris The Conflict of Laws 3ed (1984) 234. See also, Cheshire, North and Fawcett Private International Law 14ed (2008) 707; Jacobs v Credit Lyonnais [1884] QBD 589; XAG v Bank [1983] 2 Lloyd's Rep. 535; and for an in-depth perspective on South African law on this point see Schulze "Conflict of Laws" 2006 Juta's Annual Survey 836-840.

14 Cheshire, North and Fawcett 708-710.
} 
(Pty) $L t d{ }^{15}$ In this case the issue that arose was which system of law governs the transfer of ownership of a ship. This case is also useful in illustrating the application of the Admiralty Jurisdiction Regulation Act of 105 of 1983 in a scenario involving conflict of laws. ${ }^{16}$ The creditor in this case was a German Bank, Marcard Stein \& Co (Marcard Stein). This bank submitted a claim based on a cession to it of the claim of London Steamship. The alternative claim was based on a mortgage bond registered over the vessel in favour of Marcard Stein for US\$16,5 million on 1 June 1992.

Marcard Stein objected to the claims of other creditors on the ground that on 29 May 1992 the then owner of the vessel, Verena Shipping Co (Verena) sold the vessel by bill of sale executed in London to Alvo Shipping Co Ltd (Alvo). The referee, unable to deal with the issues arising from the alleged sale and delivery of the vessel, sought to obtain a ruling by the court thereon. This resulted in six of the creditors who had proved claims against the fund making an application to the trial court for an order inter alia, that the sums claimed by them be paid to them from the fund. ${ }^{17}$

The court a quo found that the applicants had made out a case for the relief which they sought and granted the order. However, with leave of court a quo Marcard Stein appealed to the Appellate Division seeking a reversal of the decision of the court a quo citing as respondents the six applicants and the fund. The appeal court stated that the case before it hinged on the basic question of whether in law the execution of a bill of sale by itself (without delivery) resulted in the ownership of the ship MV Gulf Trader aka MV Vicky passing from Verena to Alvo.

In dealing with this question the court extensively dealt with the concept of passing of ownership in corporeal movable property and conflict of laws, ${ }^{18}$ with the result that the application was dismissed with costs as was clearly

1519953 SA 663 (A); see also Ultisol Transport Contractors Ltd v Bouygues Offshore 19961 SA 487 (C); Epol (EDMS) BPK v Sentraal-Oos (KOÖPERATIEF) BPK 19971 SA 505 (O); Nedcor Bank Ltd v ABSA Bank Ltd 19982 SA 830 (W); MT Argun Sheriff of Cape Town v MT Argun, her Owners and All the persons Interested in her, Sheriff of Cape Town v MT Argun, her Owners and All persons interested in her 20013 SA 1230 (SCA); and MV Mega $S$ Bridge Oil Ltd v Fund Constituting Proceeds of the sale of the MV Mega S (Formely MV Aksu) 20073 SA 202 (C). The case of Marcard Stein \& Co v Port Marine Contractors (Pty) Ltd supra has been discussed in depth in this paper as it reflects the most current position that reflects the sentiments of most national and international jurisdictions when choosing the most appropriate system of law in cases involving international sales. Therefore this case forms a classic example of guidelines for the selection of proper law particularly in commercial transactions that affect and are most pertinent to diamond trade.

16 The facts of the case are that a corporation known as London Steamship Owners Mutual Insurance Association Ltd (London Steamship) arrested the vessel MV Gulf Trader on 20 May 1992 while she was berthed in the East London Harbour in pursuance to an action in rem instituted by the corporation for the payment of a sum of US\$870 048, 89 in respect of an unspecified maritime claim. The name of the vessel was subsequently changed to the MV Vicky. Again on 23 May 1992 the same vessel was arrested at the instance of another company Gulf \& Continental Bunker Fuels Co Ltd (Gulf \& Continental) in an action for the recovery of US $\$ 35625,00$ for the supply of bunkers during April 1992.

17 666E-G.

18 667A. 
outlined by Corbett $\mathrm{CJ}$ in his judgment with Botha JA, Nestadt JA, Nienaber $\mathrm{JA}$ and Marais JA concurring. ${ }^{19}$

In his judgment, Corbett $\mathrm{CJ}$ declared that it is a fundamental principle of our common law that ownership in corporeal movable property does not pass by virtue of a contract of sale alone. A proper delivery of the goods of contractual description must be made to the purchaser. However, when a South African court exercises its admiralty jurisdiction, as it was in this case by virtue of section 6(1)(a) of the Admiralty Jurisdiction Regulation Act 105 of 1983, English admiralty law, including relevant principles of English private international law, was applicable in this matter. It was agreed by all parties that in terms of English domestic law that, "a ship is regarded as a personal chattel (any tangible movable property) and that a bill of sale, duly sealed, signed and delivered would have caused the property in the vessel to pass to the purchaser and delivery was not necessary".

The court of appeal established that prior to the sale of the vessel on 29 May 1992 she was registered in the Bahamas and sailed under a Bahamian flag. The bill of sale indicated that the sale was registered by the registrar of Bahamian ships in London at 3:50 pm on 1 June 1992 and the mortgage of the ship in favour of Marcard Stein was registered in that registry on the same day 5 minutes later at 3:55 pm. The interesting aspect of the case here is that factually the vessel was still under arrest and located in East London Harbour during the sale on 29 May 1992.

On the basis of these facts, the court held that the general principle of English private international law to be applied to the transfer of corporeal movable property is the lex situs. This means the law to be applied is the law of the place where the property is to be found at the time of the transaction in question (in this case, South African law). ${ }^{21}$ The actual situs of the vessel was established in this case as the vessel was not on the high seas but had been located at the East London harbour for at least nine or ten days at the time of the sale. ${ }^{22}$

It was held by the court that there are five reasons for choosing the lex situs as choice of law in English law this instance, mainly: ${ }^{23}$

1 That the rule refers the passing of ownership to the system of law pertaining to the jurisdiction which has effective power over the property in question.

2 That the rule is normally simple to apply and makes for certainty in that it does not lead to multiple solutions since the property can only be in one place at a time.

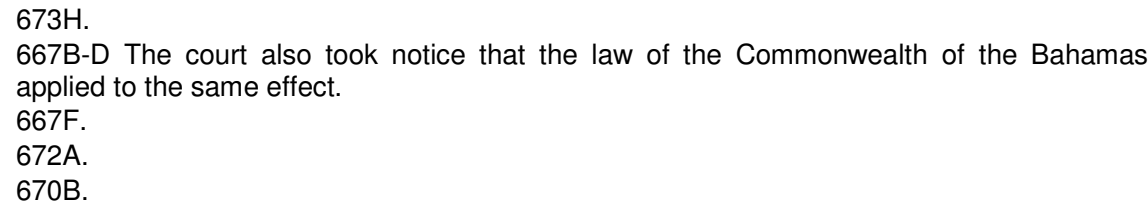


3 That it satisfies the expectations of the reasonable man, for a party to a transfer naturally concludes that the transaction will be subject to the law of the country in which the subject-matter is at present situated.

4 That property passes at the place where the goods themselves are.

5 That commercial convenience imperatively demands that proprietary rights to movables shall generally be determined by the lex situs.

With regard to the question of delivery, the court held that in order to transfer ownership in a res or chattel by way of constitutum possessorium there should exist an agreement to the effect that the transferor should hold the property in question on behalf of the transferee. ${ }^{24}$

\section{Diamond sales and the lex situs}

The principle of passing of ownership in the context of international trade applies in case of any other chattel including diamond sales. However, the location of a diamond at the time of sale cannot strictu sensu be compared to that of a ship even though diamonds are also registered for trade purposes. This is because diamonds are personal chattel and more capable of being easily located for the purposes of sale and passing of ownership and therefore they do not require an artificial situs. It is submitted that the situation may be different where the diamonds are being sold while en voyage and being sold via a negotiable bill of lading. However, the important aspect of diamond sales in the context of international trade is that the lex $s_{i t u s}{ }^{25}$ is the system of law to be applied when diamonds are being sold.

The concept of lex situs was confirmed in Randfontein Estates Gold Mining Co Ltd $v$ Custodian of Enemy Property, ${ }^{26}$ Boyd $v$ CIR, ${ }^{27}$ where the court declared in both cases that in respect of shares (which are incorporeal movable property and are not capable of physical location) for all purposes in law a bearer share is "situated" at the place where the company is incorporated. A share which is registered in the name of a member in the register of members is "situated" at the place where such a register is kept.

\section{PRESCRIPTION OF CLAIMS AND DEBTS}

The prescription of debts is an important area in conflict of laws which affects international trade, whether such trade involves diamonds or any other commodity. A debt created must be brought into the jurisdiction of a court for enforcement within the prescribed period or such as a debt

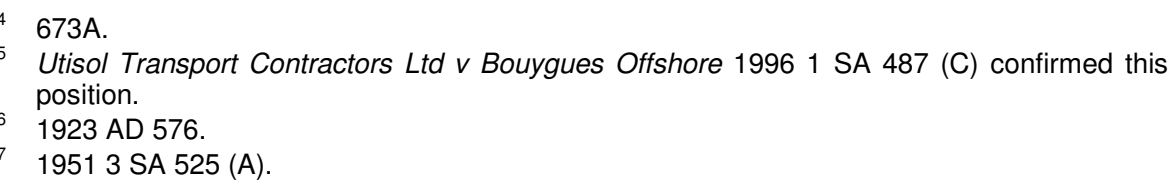


prescribes. $^{28}$ Each jurisdiction has its own unique system of law for determining the period. Diamond dealers must be aware of the periods of prescription that may affect their commercial transactions in the context of international trade. This international trade law question involving a conflict of law aspect was settled by the Supreme Court of Appeal in two matters heard together, referred to as Society of Lloyd's v Price; Society of Lloyd's v Lee. $^{29}$

These cases are essential in providing guidelines as to the system of law to be applied in matters of determining the prescription period in international trade transactions. This case, although involving protracted technical legal considerations of conflict of laws in nature, serves as an important case which demonstrates a peculiar situation. The peculiarity is evident in the judgment where the true sense of the categorization of laws for the purpose of conflict of laws, showed that there was technically no system of rules that could be applied to the case due to the nature and categorization of the rules and systems being considered before the court.

It was heard on appeal that a provisional sentence summons alleged that the English court was a court of competent jurisdiction because the original contract of insurance in question had made English law to be applicable to the agreement. ${ }^{30}$ The plea was three-pronged namely, (1) that Lloyd's claims had become prescribed by virtue of the provisions of the South African Prescription Act 68 of 1969, (2) that the English court did not have international jurisdiction in terms of South African law to grant judgments, and (3) that it would be against public policy as determined by South African courts to recognize and enforce the judgments in South Africa. The court a quo judge had taken the view that Lloyd's claims had prescribed and as a result refrained from making any findings on point (2) or (3) above. ${ }^{31}$

On the issue of prescription it must be noted that the claims (embodied in the provisional sentence summons) were based on default judgments issued by the English court more than three years but less than six years before. The defendants were served with the summons in South Africa. Lloyds were arguing that English law ought to apply to determine the issue of prescription in terms of section 24 of the English Limitation Act, 1980 which provided that an action cannot be brought upon any judgment after the expiration of six years from the date on which the judgment became enforceable. It also

28 In South African shipping law, which upholds the Hague-Visby Rules claims based on bills of lading must be enforced within a year to avoid prescription of such claims.

2920065 SA 393 (SCA). This case discussed the via media approach to conflict of laws which was recently considered in Laurens NO v Von Hone 19932 SA 104 (W). It is submitted that this approach contributes to the more amicable co-existence of states in commerce in global trade. It works in a manner that can be summarized as follows by commercial men and women, "Yes, all states have their unique way of conducting matters and making decisions but how do we find the best way forward in light of all these legal system conflicts seeing that we are required by trade laws to co-exist and co-operate?" The via media approach then steps in to suggest the best system of law that will be most equitable in the circumstances.

$30397 \mathrm{~B}$

31 399A-C. 
provided further that no arrears of interest in respect of any judgment debt shall be recoverable after the expiration of six years from the date on which such interest became due. ${ }^{32}$

In terms of the South African Prescription Act, ${ }^{33}$ which the respondents were arguing ought to apply, the claims would have prescribed after the lapse of three years unless the judgments of the English courts were deemed to be judgment debts. In such a case the prescriptive period would be thirty years. ${ }^{34}$ The court of appeal dealt with the special plea of prescription by considering firstly the question of which system of law between the two ought to apply to determine the question of prescription.

According to the appeal judge in this case, Van Heerden JA, the via media approach was useful since it was developmental in nature and is acceptable in the area of private international law. He therefore took the view that the South African Prescription Act is one which is substantive in nature, and therefore not one to be determined according to the lex fori. Further, by taking the via media approach to this conflict of laws, the appeal court was able to consider all sources of conflict in law (both the lex fori and the lex causae) and guided by policy to determine the most flexible and sensitive manner as to which law was applicable. In answering this question the court stated that in terms of South African private international law procedural matters are governed by domestic law of the country where the matter is being heard, (the lex fori). However, matters of substantive law are governed by the law which applies to the underlying transaction or occurrence, also known as proper law or lex causae. This principle is the same under English law. ${ }^{35}$

To further illustrate the correct system of law applicable, the court deliberated on two types of prescription (limitation) laws. The first type is referred to as extinctive prescription which extinguishes a right and is regarded as substantive in nature. The second type is referred to as a procedural bar which imposes a procedural bar once an action has been instituted. ${ }^{36}$

The appeal court stated that according to the English Limitation Act, 1980 prescription is a procedural matter which must be governed by the lex fori (South African Law). Counsel for Lloyd's also argued that in determining whether the provisions of the English 1980 Act were procedural or substantive in nature, the appeal court should use the via media approach.

The via media, also known as the dual approach, has been considered by various writers in South Africa to cast some light as to what it entails in practice. Roodt submits that the via media approach is very useful in cases where the judiciary has to deviate from the traditional classification of law in

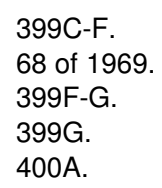


order to determine which of the systems of law is actually applicable. This is possible with the via media approach because it allows the classification (of law) that would allow the designated law (proper law) to have features that contain both formal and substantive validity of the agreement with regard to the property involved, movable or immovable, as well as the legal effect of such an agreement. ${ }^{37}$ We shall note through the discussion of the case at hand why this feature of the via media approach is important.

Neels submits that the correct understanding of the via media approach was captured correctly in a textbook by Schwimann ${ }^{38}$ which supports a more flexible approach to conflict of laws. Certainty must be insisted upon only where the factors are crystal clear as to which law ought to govern the contract at hand. ${ }^{39}$ It is submitted with respect that flexibility in private international law is essential although it does create an unsettling feeling of uncertainty on the choice of law. However with the world becoming more closely connected it is essential to have due regard to more flexible approaches to private international law provided this will promote justice. The via media approach seems to promise such relief in principle. It is also clear that the via media approach can be understood as being closely connected with the German principle of Günstigkeitsprinzip which suggests that in conflict of laws situations the most favourable law must apply in a particular situation. ${ }^{40}$

This approach has the effect that the court will consider both the lex fori and the lex causae to determine the correct characterization of law to be applied. It is intended to create international harmony, allowing the cases to be decided the same way regardless of in which countries the matters are heard. The result would create a gap in law where under South African law, (lex fori) prescription is a matter of substance and not procedure, therefore, South African law does not apply. On the other hand, under English law, (lex causae), the prescription provision is procedural in nature so it does not apply either. ${ }^{41}$ This is also a gap created particularly because a South African court will not enforce procedural rules of foreign courts in matters heard by it. ${ }^{42}$ It appeared prima facie in this case that there were no prescription rules applicable to the arbitration awards before the court.

37 Roodt "Conflict of Laws and Autonomy in Antenuptial Contracts" 2006 THRHR 367; and Neels "Via Media Classification in Private International Law" 1994 THRHR 687 692-694; 2003 SALJ 884-885. It is the writings of Professor Neels that were used by the court in casu to make a decision on the appropriate law to be applied. See also, Laurens NO $v$ Von Hohne [1993] All SA 322 (W); Edwards Conflict of Laws LAWSA Vol 2(2) 2ed (2003) par 285.

38 Schwimann Internationales Privatrecht (2001), cited in Neels 2003 SALJ above in fn 37.

39 Neels "The Music Performance Contract in European and Southern African Private International Law (2)" 2008 THRHR 529530.

40 Betlem University of Southampton: Commercial Conflict of Laws Seminar 15 (2009) 1.

41 See, Laconian Maritime Enterprises Ltd v Agromar Lineas Ltd 19863 SA 509 (D) for discussion of similar situation relating to prescription of debt.

42 403J-I. 
The court of appeal in making the decision as to the law to be applied warned against the bias in favour of the lex fori, but advised that a court should follow the via media approach which is aimed at serving individual justice, equity, convenience with consideration for international harmony in disputes with an international character. ${ }^{43}$ With these considerations in mind it was held by the court that harmony of law suggests that claims which are alive and enforceable in terms of the law of the country under which such claims arose (in this case English law) should also be enforceable in South Africa. It was stated that the legal system which has the closest and most real connection with the agreement should be chosen and be applicable.

The court of appeal also denied the application of the lex fori on the basis that the provisional sentence summons was not a matter of procedural execution, as argued by defendant's counsel, but a means of obtaining an enforceable judgment on the basis of an English judgment already obtained. In effect the provisional sentence worked as a second judgment. ${ }^{44}$ Therefore, as a result, the court found that the lex causae was applicable in this case with the result that the English Limitation Act, 1980 was applicable. In terms of the 1980 Act the provisional sentence summonses were not prescribed as they were brought within the six-year period contemplated in the Act. ${ }^{45}$

It is submitted that the appeal court in this matter correctly applied the via media approach. As reiterated by Van Heerden JA in concurrence with Van $\mathrm{Zyl} \mathrm{J}$ in the factually similar case of Laconian Maritime Enterprises Ltd $v$ Agromar Lineas $L t d,{ }^{46}$ where parties had agreed that the law applicable to their respective transactions is English law, this means that they also agreed that the rules relating to procedure would be the lex fori. However, the effect of this is that parties may inadvertently in case of prescription rules agree to a situation where their rights continue to exist under the English law but become extinguished when the lex fori procedural law is applied. It was stated by the court that this could not be said to be what the parties intended. ${ }^{47}$ The application of the lex causae prescription rule in this case gave rise to an equitable and just conclusion. It was also stated by the appeal court that provisional sentence is an established procedure for enforcing foreign judgments in South Africa. In this case, the foreign judgment is not directly enforceable but constitutes a cause of action that is actionable in South Africa. ${ }^{48}$

The requirements that have to be met to qualify enforcement of a foreign judgment are that the court which pronounced such a judgment had to have had acceptable jurisdiction to do so in terms of law, such a judgment had to be final and conclusive in that it not to have been superannuated. It had not

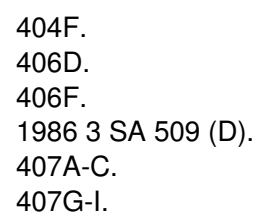


to have been also contras bonos mores and it had not to be fraudulently obtained. Further, it had not to involve the enforcement of a penal or revenue laws of a foreign state, the enforcement of such a judgment had not to be precluded in terms of the Protection of Businesses Act, ${ }^{49}$ as amended. ${ }^{50}$ The court investigated each of these requirements in depth and found that the English judgments were sound in law. It was held that the judgments were enforceable by way of provisional sentence and the appeals were upheld with costs. ${ }^{51}$

This case is extremely useful in matters particularly where a gap exists even after an enquiry as to the possible applicable systems of law. The main guidance proposed by this decision is to consider the system of law most real and closely connected to the dispute in question. It is submitted that the closest system of law approach coincides with the rationale behind the lex situs approach. On the other hand it is arguable that this is just another technical legal reneging by the courts where they refuse to commit to a system of law in the name of accommodating international harmony. The outcome of this case would have been the same if the lex causae was chosen without a long-winded debate about procedural or substantive issues of prescription. Ultimately the lex causae was the most appropriate law to be applied in this case by any standard.

\section{International instruments}

\section{Convention on the Limitation Period in International Sale of Goods, 1974}

It is important for any analysis of diamond regulations law to consider prescription in international sales in light of the Convention on the Limitation Period in International Sale of Goods or Limitation Convention (New York, 1974) as amended by the 1980 Protocol (Vienna, 1980). Both entered into force together on 1 August $1988 .^{52}$ It is important to note at the outset that the Limitation Convention, 1974 does not form part of South African law in that South Africa has neither acceded to nor ratified such Convention. It is nevertheless useful in the context of diamond regulations law as diamonds are subject to international sale transactions involving South African companies or entities. Thus the Convention may be considered by our

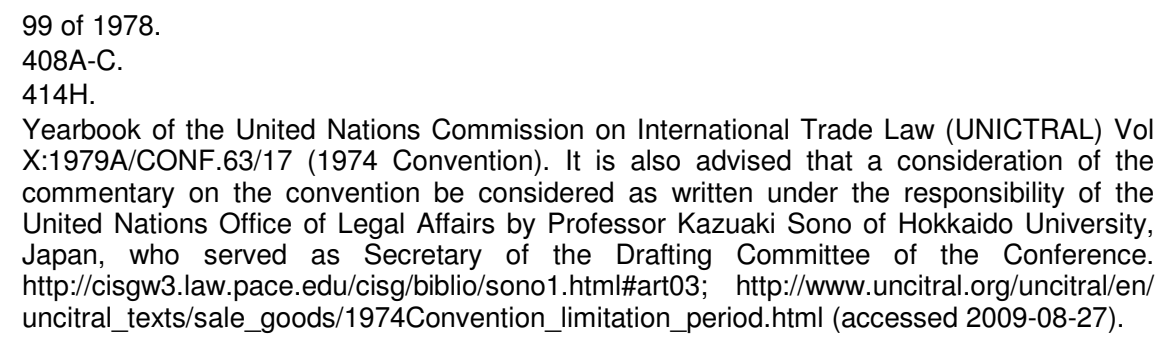


courts where matters of prescription or limitation as provided for in the language of the Convention arise.

In a country with active international sales as covered by the Limitation Convention, 1974 it is natural that the international instrument governing such transactions be considered as it may provide guidance on choice of law rules applicable to such issues as prescription Further, if the Convention proves not to be a red herring in South African law, then it should be made part of our domestic legislation.

The Limitation Convention, 1974 arose from a belief that an adherence to uniform rules governing the prescriptive period in international sale of goods will contribute to the improvement of world trade that clearly included diamond trade. ${ }^{53}$ The Convention directly applies to situations where the buyers and sellers' claims against one another arising out of an international sale contract cannot be enforced by reason of the expiration of a period of time whether such claims arise out of a breach, termination or invalidity of such contract. ${ }^{54}$

Article 3 of the Convention provides that the Limitation Convention, 1974 shall apply only in circumstances where at the time of conclusion of the contract the parties' places of business are situated in Contracting states or if conflicts of laws rules dictate that the law of the Contracting state is applicable. ${ }^{55}$ This would be a typical case where a South African court determining an international sale contract may be compelled to apply the provisions of the Limitation Convention, 1974 as provided by this provision. On the other hand it is open to parties to exclude the application of the Limitation Convention, 1974 if they so wish in terms of article 3(2). ${ }^{56}$

The Limitation Convention, 1974 expressly excludes certain goods and commodities from its ambit and these include goods bought for personal, family or household use, goods sold by execution, shares, investment securities, stocks, money and ships among others. ${ }^{57}$ An exception to this rule involves a situation where the seller before the conclusion of the contract did not have knowledge that such goods were being bought for such purposes. ${ }^{58}$ This means that the Convention will apply to a sale involving diamond sales most likely as raw materials, for example rough diamonds as part of transnational sales, in the context of international trade but not as products strictly for personal use, for example, the Convention may not be relied on for a breach of contract involving a sale of a diamond engagement ring sold by a South African store to a private individual in the United States.

\footnotetext{
Preamble.

Part I Article I substantive provisions and sphere of application of the Convention.

Article 3(1)(a)(b).

Clearly it is the intention of UNICTRAL to respect parties' freedom of contract as created by this provision of the Limitation Convention, 1974.

57 Article 4(b).

58 Article 4(b)-(f).
} 
The crucial provision of the Limitations Convention, 1974 is that it provides that the prescription period shall be four years. ${ }^{59}$ Article 9 and 10 provide for the determination of the prescription period. ${ }^{60}$ Article 13 to 21 of the Convention deals with the cessation and extension of the limitation period while the rest of the Convention deals with other technical matters such as the limit of the prescription period, effect of expiration of the prescriptive period, calculation of the period, international effect of the Convention.

The Limitation Convention, 1974 when compared to South African contract law and the law of prescription is not entirely a red herring in spite of the sophisticated and well-developed legal rules already well established in our law. It is submitted that the Convention has two unique features which may further contribute to the development of South African law, particularly pertaining to international diamond sales and other international sales generally. The first feature is that it settles the issue of application of conflict of laws in South African courts. The adoption of the Convention will result in international harmony with regard to the uniform calculation of time to protect the enforcement of claims and ameliorate the situation where there are vast differences in systems of laws concerning the calculation of time for the enforcement of claims.

The second useful feature of the Limitation Convention, 1974 is that it extends the overall limitation period to ten years maximum from the date of original commencement of the period. ${ }^{61}$ This maximum period of the Convention for a commercial claim is a glaring disparity with South African law on prescription in terms of the Prescription Act. ${ }^{62}$ It is submitted that the

59 Article 8. The Convention does provide in Articles 22 and 23 for an extension or recommencement of the limitation period subject to the provisions of the Convention.

60 "Article 9

1. Subject to the provisions of articles 10, 11 and 12 the limitation period shall commence on the date of which the claim accrues.

2. The commencement of the limitation period shall not be postponed by:

(a) a requirement that the party be given notice as described in paragraph 2 of article 1 , or

(b) a provision in an arbitration agreement that no right shall arise until an

Article 10 arbitration award has been made.

1. A claim arising from a breach of contract shall accrue on the date on which such breach occurs.

2. A claim arising from a defect or lack of conformity shall accrue on the date on which the goods are actually handed over to, or their tender is refused by, the buyer.

3. A claim based on fraud committed before or at the time of the conclusion of the contract or during its performance shall accrue on the date on which the fraud was or reasonably could have been discovered."

The Convention is limited to commercial contractual claims.

61 Article 23

6268 of 1969. S 11 provides as follows:

"Periods of prescription of debts. - The periods of prescription of debts shall be the following:

(a) thirty years in respect of -

(i) any debt secured by mortgage bond; 
prescriptive period provided by the Convention is more accommodating to parties wishing to approach the courts to enforce their claims.

A more extended period of time to enforce those claims is necessary in South African law if regard is had to geographic constraints involved in intercontinental contractual agreements such as those involving diamonds. While it is admitted that the parties wishing to enforce their claims may benefit if the Convention is adopted into South African law this may create a negative effect in the courts by resulting in an overflow of sporadic enforcement of international sales claims that may further burden the already sluggish judicial process unless of course parties choose less litigious ways of settling their claims against each: two parties. It is submitted that this Convention should be tested and will work efficiently; however, it is probably a speculation to suggest that we will see more cases in our courts.

However, it is submitted that the present South African law on prescription is not fundamentally different from that of various other countries in the world. While it is advisable to retain the current three-year period before a debt/claim prescribes, it would be prudent to provide expressly for a different prescription regime where international contractual agreements and claims are concerned. This would be perfectly in tandem with the Limitation Convention provisions on prescription. The question that remains is whether or not South Africa should consider acceding to the Limitation Convention, 1974 and join the countries such as Belgium ${ }^{63}$ in the quest to achieve international harmony on the time limits set for enforcement of claims in international sale of goods. It is submitted that becoming part of the Convention is a step toward ensuring that the differences in national laws governing the limitation of claims will be uniform and as such practical difficulties created by deferring prescription periods will be uniformly addressed.

It is submitted that there appears to be no bar to South Africa becoming a Contracting State to the Limitation Convention, 1974 in its amended form seeing that the amended form of the Convention is in line with the objectives

(ii) any judgment debt;

(iii) any debt in respect of any taxation imposed or levied by or under any law;

(iv) any debt owed to the State in respect of any share of the profits, royalties or any similar consideration payable in respect of the right to mine minerals or other substances;

(b) fifteen years in respect of any debt owed to the State and arising out of an advance or loan of money or a sale or lease of land by the State to the debtor, unless a longer period applies in respect of the debt in question in terms of paragraph (a);

(c) six years in respect of a debt arising from a bill of exchange or other negotiable instrument or from a notarial contract, unless a longer period applies in respect of the debt in question in terms of paragraph (a) or (b);

(d) save where an Act of Parliament provides otherwise, three years in respect of any other debt."

63 Belgium is one of the countries that have recently acceded to the Limitation Convention, 1974, in its un-amended form. The Convention is in force in Belgium as of 1 March 2009. 
of other international instruments such as the United Nations Convention on Contracts for the International Sale of Goods, 1980 (CISG). ${ }^{64}$

\section{International Sale of Goods, 1980 (CISG)}

As a significant part of the discussion above, the legal regulatory framework for the international sale of goods is dominated by the 1980 United Nations Convention on Contracts for the International Sale of Goods (CISG), as well as other regional and multilateral agreements between states. It is important to note that modern international trade is dominated by the rules of the World Trade Organization, and this international body has assumed huge significance in regulating global trade. However, this body regulates international trade and not strictly international sale of goods and for this reason it is of little significance in regulating international contracts. The CISG is therefore the main instrument on the regulation of international contracts. The Convention is useful in the international trade of diamonds which involves various contractual agreements between different state and non-state entities. The CISG is useful to the debates and contributions relating to matters of private international law and diamond trade transactions particularly if such diamonds are sold as part of international trade.

The CISG applies to contracts of sale of goods between parties whose places of business are in different states which states are contracting states. ${ }^{65}$ It also applies when owing to the rules of private international law, the law of a contracting state applies and in that process bringing the Convention for consideration. ${ }^{66}$ This is significant; if one party is from a contracting state, but both parties have places of business in other countries not party to the Convention, the Convention can apply. ${ }^{67}$ This is common in import and exports regulations where international law becomes inwardly or outwardly applicable as a result of the trading relationship and the commercial agreements between parties from different states.

The Convention does not apply to sales involving particular goods for instance, personal or household goods, goods being sold by auction or sales in execution, sale of securities, shares or stocks, ships, vessels and aircraft as well as electricity. This means that the Convention contemplates commodities which have been, or have emerged to be subject of international trade ${ }^{68}$ such as diamonds but probably in their unpolished form because most beneficiated diamond products or jewellery falls into the category of goods used for personal reasons.

\footnotetext{
64 The South African Legislature has stated in the Convention on Agency in the International Sale of Goods Act 4 of 1986 that the aims of the CISG should be borne in mind, see the Schedule of the Agency Act 1986.

65 Article 1(a).

66 Article $1(\mathrm{~b})$.

67 Weizuo "The Conflict of Laws in the Context of the CISG: A Chinese Perspective" 200820 Pace International Law Review 115118

68 Article 2 .
} 
The CISG codifies the provisions for parties in relation to the contract, ${ }^{69}$ formation of the contracts, ${ }^{70}$ formalities, ${ }^{71}$ and issues of offer, intention of the parties and acceptance and communication of the acceptance. ${ }^{72}$ The principles underlying the CISG provisions reflect the common-law position, which position informs modern South African law of contract. The CISG has therefore not altered the common law, making it less difficult for South African courts to interpret and apply the law.

The second part of the CISG is devoted to rules for the sale of goods. Again these rules reflect the common-law position on the law of sale. In interpreting these rules and principles in the international context, South African courts are free to refer to their own common-law background as this provides the source for most of the rules in the CISG. Further, South African traders who would be affected by the CISG would not find it difficult to know what the international legal position will be since the domestic law is not fundamentally different with international law regarding international contracts.

Another branch of law contemplated by the CISG is private international law, as the intended primary focus of this paper. The CISG does not amend, alter or change universally accepted choice of law rules and conflict of law principles. Accordingly, if a party has more than one place of business, the official place of business is that which has the closest relationship to the contract and its performance. ${ }^{73}$ If a party does not have a place of business, reference is made to its habitual residence. ${ }^{74}$ These rules are primarily found in private international law. The CISG therefore adopts the current legal positions in relation to private international law.

The whole tenor of the CISG is advantageous to local diamond companies involved in the import and export of rough diamonds where issues of harmonious and uniform application of sales law is brought into question between South Africa and its foreign trading partners. It is submitted that the sophistication of modern trade and commerce requires an understanding of the legal regulatory framework by those involved in the activity. It is highly risky to carry on international transactions without understanding the legal regulatory framework that governs those transactions. Private and state entities that contract would greatly benefit if the legal regulatory framework is fundamentally similar to their own as this tends to promote and facilitate trading since the playing field will not be full of uncertainties or surprises for local commercial entities. At this stage is sufficient to point out the basic rules on conflict of laws as provided for in the CISG. These rules show that they are supportive of the traditional legal approaches to the determination of proper law in conflict of laws disputes.

Article 1.

Article 14

Article 11.

Article 18.

Article 10

Ibid. 
Therefore there is a justifiable place for the CISG in South African private international law.

\section{The Geneva Code on Bills of Exchange}

In the conjunctive part of this paper domestic law on bills of exchange and conflict of laws will be discussed. However, it is important in this part of the brief consideration of international instruments to look at the international uniform code that may be relevant to bills of exchange in the international trade context. This code is in the form of the Convention Providing a Uniform Law for Bills of Exchange and Promissory Notes (Geneva, 1930), The League of Nations and the 19 March 1931 Convention for the Settlement of Certain Conflicts of Laws in Connection with Cheques are the result of one of several attempts made to harmonize the different national systems of law applicable to bills of exchange.

An example of a situation showing a need to settle such conflict is evident in a situation where, for example, a bill of exchange in diamond trade may be drawn in Johannesburg, issued in Paris and indorsed in London and accepted in London payable at a bank in Cologne. The Geneva Convention and the Convention on Conflict of Laws in Connection with Cheques were adopted by most European Countries but not Great Britain, the United States or the commonwealth countries. ${ }^{75}$ These codes, however, may be considered for persuasive authority in the development of rules relating to conflict of laws in South Africa.

\section{RELEVANT DOMESTIC LEGISLATION}

\section{Bills of Exchange}

Bills of exchange form a large part of international commerce due to recognized financial systems in the world. Many of the diamond trade transactions are evidenced by the use of bills of exchange to allow for a sense of financial liquidity in such sales. Bills of exchange commonly used in diamond sales may take the form of cheques and letters of credit. However, it is submitted that through the existence of sophisticated banking practices moneys can be transferred through EFT transactions.

Very briefly the letters of credit, as an example of a common bill of exchange in diamond sales, work as follows: the documentary credit has evolved as documentary credit also known as a documentary letter of credit, commercial letter of credit, commercial credit, bankers' commercial credit or a credit meaning "an independent undertaking by a bank, acting as mandatory for its customer (for example, a local buyer), to pay the beneficiary (for example a foreign seller) a stipulated sum of money against

75 Malan and Pretorius Malan on Bills of Exchange, Cheques and Promissory Notes 4ed, (2002) 269, example as given by authors. 
the presentation of stipulated documents (for example, bills of lading (used in shipping, for instance), commercial invoices and insurance documents)". ${ }^{76}$

The purpose of documentary credit (a letter which comes into existence by formal written application by the applicant) is to facilitate dealings between merchants in different countries by guaranteeing payment to the seller whilst ensuring delivery to the buyer of the goods of contractual description. Four parties are involved in sale by documentary credit, namely the applicant (usually the importer or buyer), the issuing bank, the notifying bank (which may bind itself as the confirming bank) and the beneficiary (usually the seller/exporter). There is much involved paper trail in such transactions as the parties deal with documents and not with the goods. Services or other performances under the transaction covered by the documents as credits are by their nature separate transactions from sales or other contracts on which they are based. ${ }^{77}$ These transactions may potentially fall prey to the question of conflict of laws.

Fortunately for South Africa, the laws governing bills of exchange anticipate and make provision for conflict of law scenarios involving bills of exchange. Conflict of laws concerning bills of exchange is contained in the Bills of Exchange Act. ${ }^{78}$ Section 70 of the Act provides for "Rules if laws conflict".

The Act provides that if a bill drawn in one country is negotiated, accepted or payable in another, the rights, duties and liabilities of the parties thereto are determined by the validity of the bill as regards requisites in form is determined by the law of the place of issue. ${ }^{79}$ This means that if $A$ prepares a bill and it is issued in Durban, South Africa, and negotiates it to $B$ who is in Nigeria, any dispute regarding the form of the bill must be determined in accordance with South African law.

With regard to validity of the bill as requisites in form of any supervening (subsequent) contract such as acceptance, indorsement or provision of an aval is determined according to the law where such a supervening contract was made. ${ }^{80}$ Thus, in keeping with the illustration above, if $A$ and $B$ complete the supervening contract regarding the bill of exchange in Nigeria where for instance B accepts and indorses the bill in Nigeria, the law to be applied is Nigerian law as that would be the place where the supervening contract is made.

76 Itzikowitz and Du Toit (original text by Gering) Banking and Currency: Business of Commercial Banking Documentary Credits LAWSA Vol 2(1) (2003) par 379. See, also Willis Banking in South African Law (1981).

77 Ibid. The banks are not concerned with the or bound by other contracts underlying the credit agreement even if such contracts are included in the credit. Further, documentary credits are increasingly being used in domestic transactions as well. See Ex Parte Sapan Trading (Pty) Ltd 19951 SA 218 (W); and United City Merchants (Investments) Ltd v Royal Bank of Canada [1982] All ER 720.

7834 of 1964.

79 S $70(a)$

80 lbid. 
However, the Act provides that a bill is not invalid by reason that it is not stamped in accordance with the law of the place of issue. Further, a bill issued outside the Republic which conforms in form to the law of South Africa may for purposes of enforcing payment thereof be treated as valid as between all persons who negotiate, hold or become parties to that bill in the Republic. $^{81}$ This provision is useful to the rapid movement of matters regarding such bills of exchange within the Republic's courts. Further, the Act favours the validity of a bill of exchange rather than its invalidation.

Section 70(b) deals with interpretation of the contract and provides that, the interpretation of the contract of the drawer, indorser, acceptor or signer of an aval of a bill in determined by the law of the place where such contract is made, provided that if a bill payable in the Republic is indorsed outside the Republic, the indorsement shall as regards the payer be interpreted according to the law of the Republic. This provision serves to simplify the determination of the substantive laws applicable to the payer of an indorsed bill of exchange regardless of the endorser's place of origin. Further, this provision captures the rule that the law of the place of contract applies as the applicable law (lex contractus) where there is no chosen law and under certain circumstances.

The duties of the holder with regard to presentment for acceptance or payment are determined by the law of the place where the act is done. If a bill is dishonored, a protest or notice of dishonour is determined by the place where the bill is dishonored. ${ }^{82}$ Where a bill is drawn outside the Republic but payable in the Republic and the sum payable is not expressed in currency of the Republic, in the absence of contrary indication the amount shall be calculated according to the rate of exchange for sight drafts at the place of payment on the day the bill is payable. ${ }^{83}$

With regard to determination of date of payment for a bill drawn in one country and payable in another, such date shall be determined according to the law of the place where the bill is payable ${ }^{84}$ Clearly the Legislature has resolved the legal lacunae regarding essential elements of a bill of exchange.

It is submitted that South African bills of exchange law conforms to international expectations where cases with a foreign element are involved. This argument is based on the notion that South Africa, as a member of the International Chamber of Commerce (ICC), adheres to the business practices that are deemed acceptable and sound for the international business community. The bills of exchange statutory framework does not go against the spirit of commonly accepted Roman-Dutch rules on conflict of laws. In fact, the Bills of Exchange Act codifies some of the principles and

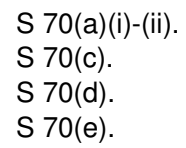


further seeks to incorporate commonly known choice of law rules within the statutory framework.

\section{Admiralty Jurisdiction}

Maritime law, especially the carriage of goods by sea is crucial in the context of international trade particularly where the commodities are transported by sea. It should, however, be stated at the outset that the common mode of transport of diamonds is air transport for reasons of safety, security and low risk. In South Africa carriage of diamonds by ship is limited to circumstances where there is mining of sea areas involved, as demonstrated by De Beers Marine (Pty) Ltd a Cape Town based company contracted to De Beers Consolidated Mines Ltd for the purposes of mining the west coast sea area of southern Africa. Therefore, diamond shipment and admiralty law must be understood only in light of those diamond activities (that is, the mining of sea areas).

Diamonds may, however, be subject to shipments within the area of imports and exports. ${ }^{85}$ This can therefore give rise to maritime claims. The Admiralty Jurisdiction Regulation $\mathrm{Act}^{86}$ which states the law to be applied by South African courts may be of assistance in these instances. This provision indirectly makes provision for creating clarity with regard to choice of law rules applicable should such a situation present itself to a South African court in the exercise of its admiralty jurisdiction.

The Act makes it possible for English statutes to be applicable to South African maritime matters as far as it reflects English admiralty law as it stood at the commencement of the Act (that is, 1 November 1983). In terms of section 6(1)(a) of the Admiralty Jurisdiction Regulation Act, ${ }^{87}$ foreign law in the form of English law is applicable to maritime matters in the Republic.

Section 6(1)(a) of the Act provides that in respect of those heads of jurisdiction, which the colonial court of admiralty derived from the English Colonial Courts of Admiralty Act, 1890, English law as at 1 November 1983 (the date of commencement of this Act) is applicable. An English decision made after 1 November 1983 is still applicable as a useful precedent in South Africa, provided that it reflects English admiralty law as at 1 November 1983. The decisions by the English courts made after 1 November must, however, be examined in order to determine whether or not they are applicable under South African law. ${ }^{88}$

85 Carriage of diamonds and other precious stones by sea is still practised in countries such as India. Only in the case where a South African party has entered into contractual obligations with a party from India, for instance for the receipt of diamonds and precious stones transported by sea, then admiralty law will play a role, otherwise the general and safest manner for carriage of diamonds is by Air with hand-to-hand secured delivery.

86105 of 1983.

87 Ibid.

88 6. Law to be Applied and rules of evidence. 
The meaning of section 6 was considered by the court a quo as well as the appeal case involving the vessel MV Stella Tingas. In MV Stella Tingas $v$ MV Atlantica (Transnet Ltd t/a Portnet, Third Parties) ${ }^{89}$ the trial court had to determine whether in terms of section 6 of the Admiralty Jurisdiction Regulation Act 105 of 1983 it is obliged to apply the law which the High Court of Justice of the United Kingdom in the exercise of its admiralty jurisdiction would have applied as at 1 November 1983. Further, the court had to determine whether the High Court of Justice would have applied the United Kingdom Pilotage Act of 1983.

The maritime matter involved revolved around the issue of liability for loss or damage caused by a ship under compulsory pilotage. It was held that a claim for damage done by a ship was a matter in respect of which a South African Court of Admiralty had jurisdiction immediately before the commencement of the Admiralty Jurisdiction Regulation Act on 1 November $1983 .^{90}$

Section 6(1)(a) of the Admiralty Jurisdiction Regulation Act $^{91}$ made English law applicable in the form of the provisions of the English statutes. The Pilotage Act, 1983 was made applicable "to all ships British and foreign". However, in this case it did not mean that the English Act could be applied outside the geographical territory of the United Kingdom. ${ }^{92}$

The application of an English statute is qualified by the extent to which that law may be applied by virtue of section 6(1) because it is only in the absence of South African Legislation that English law will apply. ${ }^{93}$ Since, in this case, a South African statute existed. This was in the form of Paragraph 10 of Schedule 1 to Legal Succession to the South African Transport Services Act. ${ }^{94}$ That Act could be applied in terms of section 6(2) of the Admiralty Jurisdiction Regulation Act. ${ }^{95}$ On appeal in MV Stella Tingas:

"1. Notwithstanding anything to the contrary in any law or the common law contained in a court in the exercise of its admiralty jurisdiction shall:

a. with regard to any matter in respect of which a court of admiralty of the Republic referred to in the Colonial Courts of Admiralty Act, 1890, of the United Kingdom, had jurisdiction immediately before the commencement of this Act, apply the law which the High Court of Justice of the United Kingdom in the exercise of its admiralty jurisdiction would have applied with regard to such a matter at such commencement, in so far as that law can be applied;

b. with regard to any other matter, apply the Roman-Dutch law applicable in the Republic.

2. The provisions of subsection (1) shall not derogate from the provisions of any law of the Republic applicable to any of the matters contemplated in paragraph (a) or (b) of that subsection." 
Transnet Ltd t/a Portnet $v$ Owners of the MV Stella Tingas and the MV Atlantica ${ }^{96}$ this point was upheld.

The Admiralty Jurisdiction Regulation Act ${ }^{97}$ empowers the court in the exercise of its admiralty jurisdiction to award damages in a foreign currency specifically in instances where the plaintiff has suffered loss in that currency. ${ }^{98}$ This section addresses conflict of laws in the calculation of currency by providing that such a calculation be done subject to any laws relating to exchange control, with fairness and equity in the decision of the court.

\section{$5 \quad$ CONCLUSION}

It is clear that South African conflict of laws branch is in tandem with trends in various parts of the world. The courts have followed choice of law rules that are commonly and almost universally applied and acceptable in various other jurisdictions. This is because persons and entities (diamond merchants in particular) from foreign countries are likely to forge contractual and commercial relationships with South African persons and entities especially when the laws pertaining to conflict of laws can be determined by well developed rules that will create certainty in the outcome of potential disputes. It is therefore important that the South African legal system, and in this case the conflict of law regulatory framework, be internationally acceptable and conforms to commonly known principles and positions found in various other jurisdictions. This discourse has accordingly shown that conflict of laws in South Africa is remarkably developed to anticipate various scenarios as are likely to arise in international diamond trading and transactions, making room for flexible approaches to the determination of the proper law to be applied. However, to encourage trade in the diamond industry and any other industry, more development is required by taking into account those instruments such as the Convention on the Limitation Period in International Sale of Goods or Limitation Convention (New York, 1974) as amended by the 1980 Protocol (Vienna, 1980).

20032 SA 473 (SCA).

105 of 1983

$98 \mathrm{~S} 5(2)(\mathrm{g})$, subject to the provisions of any law relating to exchange control, orders payment to be made in such currency other than the currency of the Republic as in the circumstances of the case appear appropriate, and makes such order as seems just as to the date upon which the calculation of the conversion from any currency to any other currency should be based. 